\title{
Protein Recommendations for Weight Loss in Elite Athletes: A Focus on Body Composition and Performance
}

\author{
Amy J. Hector and Stuart M. Phillips \\ McMaster University
}

\begin{abstract}
There exists a large body of scientific evidence to support protein intakes in excess of the recommended dietary allowance (RDA) $(0.8 \mathrm{~g}$ protein $/ \mathrm{kg} / \mathrm{day})$ to promote the retention of skeletal muscle and loss of adipose tissue during dietary energy restriction. Diet-induced weight loss with as low as possible ratio of skeletal muscle to fat mass loss is a situation we refer to as high-quality weight loss. We propose that high-quality weight loss is often of importance to elite athletes in order to maintain their muscle (engine) and shed unwanted fat mass, potentially improving athletic performance. Current recommendations for protein intakes during weight loss in athletes are set at $1.6-2.4 \mathrm{~g}$ protein/ $\mathrm{kg} / \mathrm{day}$. However, the severity of the caloric deficit and type and intensity of training performed by the athlete will influence at what end of this range athletes choose to be. Other considerations regarding protein intake that may help elite athletes achieve weight loss goals include the quality of protein consumed, and the timing and distribution of protein intake throughout the day. This review highlights the scientific evidence used to support protein recommendations for high-quality weight loss and preservation of performance in athletes. Additionally, the current knowledge surrounding the use of protein supplements, branched chain amino acids (BCAA), $\beta$-hydroxy $\beta$-methylbutyrate (HMB), and other dietary supplements with weight loss claims will be discussed.
\end{abstract}

Keywords: dietary energy restriction, dietary supplements, skeletal muscle

Elite athletes regularly expend high amounts of energy during training and competition. Weight loss in elite athletes, if desired, is commonly achieved by the introduction of a caloric deficit that consists of restriction of dietary energy combined with their training. Elite athletes undergo dietary caloric restriction for the reduction of body fat, which may be advantageous in a variety of sports including aesthetic and weight class sports to improve power-to-weight ratios as well as to improve overall athletic performance (Sundgot-Borgen \& Garthe, 2011). However, there can be an accompanying loss of lean body mass (LBM) during caloric restriction that can comprise roughly $25 \%$ of the total weight lost (Weinheimer et al., 2010). Lean body mass, a significant proportion of which is skeletal muscle, is critical for good metabolic function (i.e., site of postprandial glucose disposal, lipid oxidation, and resting energy expenditure), and, perhaps most importantly for elite athletes, skeletal muscle is crucial for locomotion and athletic performance (Wolfe, 2006). Therefore, to reduce the negative consequences of skeletal muscle loss and performance that may accompany caloric restriction, strategies to promote high-quality weight loss (i.e., the loss of fat mass while maintaining LBM) are of importance for elite athletes.

The normal maintenance of LBM is determined by continuously opposing and fluctuating rates of muscle protein synthesis (MPS) and muscle protein breakdown (MPB). For example, in the fasted state, MPB exceeds rates of MPS such that net protein balance is negative (Rasmussen \& Phillips, 2003). Consumption of a protein containing meal that contains higher quantities of essential amino acids (Volpi et al., 2003), and particularly leucine

Hector and Phillips are with the Department of Kinesiology, McMaster University, Hamilton, Ontario, Canada. Address author correspondence to Stuart M. Phillips at phillis@mcmaster.ca.
(Atherton et al., 2010), stimulates MPS while the protein-induced insulin response helps to reduce MPB (Greenhaff et al., 2008), resulting in a positive protein balance (Greenhaff et al., 2008). The responses are, however, transient with feeding and reverse within hours of not eating, leading to periods of negative energy balance. Thus, in energy balance, over the course of the day periods of positive and negative protein balance are roughly equal, resulting in stable skeletal muscle mass. Performing resistive exercise (and likely, to some degree, aerobic exercise) stimulates both MPS and MPB (Phillips et al., 1997), but sensitizes skeletal muscle to the anabolic effects of protein ingestion, resulting in a synergistic rise in MPS that, when performed repeatedly, can result in a gain of LBM over time. During dietary energy restriction, rates of MPS are reduced in the fasted and fed conditions (Areta et al., 2014; Hector et al., 2015; Pasiakos et al., 2013) resulting in net negative protein balance and loss of skeletal muscle mass (Pasiakos et al., 2013). To offset this negative net muscle protein balance, strategies such as increasing protein intake and the practice of resistance exercise that could improve muscle protein balance during dietary energy restriction are therefore critical for the maintenance of LBM.

In addition to the effect of ingestion of dietary protein in stimulating MPS, which would clearly be important for preserving skeletal muscle mass during dietary energy restriction, protein is the primary macronutrient for induction of satiety (Holt et al., 1995). During dietary energy restriction in athletes, a high degree of satiety is especially helpful and may promote compliance to reduced energy intake despite higher energy expenditure. Furthermore, many protein-containing foods are nutrient-dense foods; for example, protein from animal sources (e.g., dairy, eggs, and meat) provides essential amino acids, vitamin B12, iron, zinc, calcium, and vitamin D (Phillips et al., 2015), which would help to provide adequate nutrient intake within a lowered energy budget during dietary energy restriction. 
The purpose of this review is to highlight the current body of knowledge around the role of higher dietary protein intakes and dietary supplements during hypocaloric weight loss on LBM retention and fat mass loss in elite athletes. Where data in athletes are unavailable or limited, studies in overweight/obese adults or situations in energy balance are discussed, and the potential implications for weight loss in athletes will be highlighted. For additional weight management strategies in athletes beyond protein and dietary supplements, we refer the interested reader to a brief review (Manore, 2015).

\section{Optimal Protein Intake During Caloric Restriction in Elite Athletes: How Much Protein?}

The recommended dietary allowance for protein, determined by the nitrogen balance method is currently set at $0.8 \mathrm{~g}$ protein $/ \mathrm{kg} / \mathrm{day}$, and represents a daily protein intake level sufficient to meet the needs of nearly all individuals (Trumbo et al., 2002). However, it is clear that during dietary energy restriction, protein intakes higher than the recommended daily allowance (RDA) aid in reducing the loss of LBM (Wycherley et al., 2012) and higher protein intake in combination with resistance exercise training is necessary to fully preserve or even allow increases in LBM (Josse et al., 2011; Longland et al., 2016). In the context of a complete diet, the acceptable macronutrient distribution range (AMDR), which is the intake of macronutrients associated with lower risk for chronic disease while providing adequate intakes of essential nutrients, comprises a wide range of energy as protein from 10-35\% of total energy intake (Trumbo et al., 2002). Importantly, in situations of energy restriction, the percentage of total energy from protein will change depending on the severity of the energy deficit. Thus, the aim of this review is to focus on recommendations for dietary protein intake in $\mathrm{g}$ protein $/ \mathrm{kg}$ body mass. However, it is important to note that most higher protein weight loss diets still provide protein that is well within the AMDR.

Current recommendations for protein intake in athletes during caloric restriction span a large range. For example, a systematic review reported that resistance trained athletes require $1.8-2.7 \mathrm{~g}$ protein/kg body weight each day during an energy deficit (or 2.3-3.1 g protein $/ \mathrm{kg}$ of fat-free mass each day) (Helms et al., 2014). Of note, the maintenance of LBM during caloric restriction is affected by a number of different factors that may influence the optimal level of protein intake. Firstly, the more severe the caloric deficit (i.e., faster rates of weight loss) often results in greater losses of LBM (Garthe et al., 2011; Mettler et al., 2010). Secondly, the leaner an individual is, the more susceptible they will be to LBM loss (Elia et al., 1999; Heymsfield et al., 2011). Finally, the training status and volume of work being performed by the athletes may be a factor in determining optimal protein intakes. For example, the energy expenditure during exercise training will contribute to the caloric deficit and should be accounted for during the weight loss diet. The indicator amino acid oxidation (IAAO) method is a technique for determining protein requirements by measuring the oxidation of an indicator amino acid in response to differing protein intakes. In brief, the oxidation rate of the indicator amino acid will become stable once the protein requirement is met (Elango et al., 2008) and this noninvasive method may be useful to determine protein requirements in a variety of athletes undergoing caloric restriction. For example, the RDA of young men assessed using the IAAO method was reported to be $1.0 \mathrm{~g}$ protein $/ \mathrm{kg} /$ day (Humayun et al., 2007), significantly higher than the current RDA. Kato et al. (2016) examined the protein requirements in endurance athletes performing a simulated training program (35 km over 3 days) and following an acute $20-\mathrm{km}$ run, and reported that the RDA was $1.83 \mathrm{~g}$ protein $/ \mathrm{kg} /$ day. Acknowledging the paucity of data in female athletes, Wooding et al. (2017) investigated the protein requirements in female athletes performing variable intensity intermittent exercise and reported the estimated RDA of $1.71 \mathrm{~g}$ protein/ $\mathrm{kg} /$ day. Finally, an RDA of $2.2 \mathrm{~g}$ protein $/ \mathrm{kg} /$ day was reported in male bodybuilders on a nontraining day using the IAAO (Bandegan et al., 2017). It is important to remember that all of the data for protein requirements derived by the IAAO discussed here were conducted in energy balance, with nonathletes (Humayun et al., 2007) and athletes (Bandegan et al., 2017; Kato et al., 2016; Wooding et al., 2017) requiring much more protein than the current RDA of $0.8 \mathrm{~g}$ protein $/ \mathrm{kg} / \mathrm{day}$. Thus, the IAAO method may be useful to determine optimal protein recommendations for athletes undergoing varied training protocols and caloric restriction interventions.

To date, there are only a handful of studies investigating the effect of protein quantity on MPS and body composition during dietary energy restriction in physically active adults. Following 5 days of dietary energy restriction in healthy, resistance-trained males and females consuming 1.4-1.6 g protein $/ \mathrm{kg} / \mathrm{day}$, an acute bout of resistance exercise stimulated rates of MPS equal to levels observed during energy balance, and consumption of protein in close temporal proximity to resistance exercise resulted in elevations in MPS above rested levels during energy balance (Areta et al., 2014). In a group of physically active military personnel, consuming two and three times the RDA of protein during a $40 \%$ energy deficit for 21 days preserved the MPS response to a $20 \mathrm{~g}$ serving of protein and preserved skeletal muscle mass compared to a group consuming the RDA for protein (Pasiakos et al., 2013). Longland et al. (2016) demonstrated that during a $40 \%$ energy restricted diet in relatively trained but overweight young men, a resistance exercise and high-intensity interval training (HIT) program performed 6 days per week combined with a protein intake of $2.4 \mathrm{~g}$ protein $/ \mathrm{kg} /$ day resulted in a significant gain in LBM after 4 weeks. Interestingly, from the same study (Longland et al., 2016), despite a $40 \%$ energy deficit, the group consuming $1.2 \mathrm{~g}$ protein/ $\mathrm{kg}$ /day maintained their LBM. Equally as impressive was that the higher protein $(2.4 \mathrm{~g}$ protein $/ \mathrm{kg} / \mathrm{day})$ group lost $-4.8 \pm 1.6 \mathrm{~kg}$ of fat mass and the lower protein group (1.2 $\mathrm{g}$ protein $/ \mathrm{kg} /$ day) lost $-3.5 \pm 1.4 \mathrm{~kg}$ of fat mass in only 4 weeks (Longland et al., 2016).

In resistance-trained athletes, Mettler et al. (2010) conducted a 2-week study where subjects were also $40 \%$ energy restricted with two groups consuming either $1 \mathrm{~g}$ protein $/ \mathrm{kg} /$ day or $2.3 \mathrm{~g}$ protein/ $\mathrm{kg}$ /day. During the study, the athletes continued their habitual training regimen ( $\sim-5$ sessions per week, with at least 2 resistance training sessions). In the group consuming $1 \mathrm{~g}$ protein $/ \mathrm{kg} / \mathrm{day}$, a $-1.6 \mathrm{~kg}$ loss of LBM was reported, and in the group consuming $2.3 \mathrm{~g}$ protein $/ \mathrm{kg} / \mathrm{day}$, only $-0.3 \mathrm{~kg}$ LBM loss was reported, with similar fat mass losses in both groups $(\sim 1.4 \mathrm{~kg})$ (Mettler et al., 2010). We propose that protein intakes higher than $\sim 2.4 \mathrm{~g}$ protein/ $\mathrm{kg}$ /day during a dietary energy deficit are unlikely to confer a significant additional protein-sparing effect. Figure 1 plots the protein intake levels against changes in LBM in the studies in trained lean athletes reported in the systematic review by Helms et al. (2014), with the addition of data from Longland et al. (2016). Figure 1 shows that there is a superior preservation of LBM with elevated protein intakes and slower rates of weight loss (Helms et al., 2014). Taken together, the studies (Longland et al., 2016; 
- Fast Rate Weight Loss a Slow Rate Weight Loss

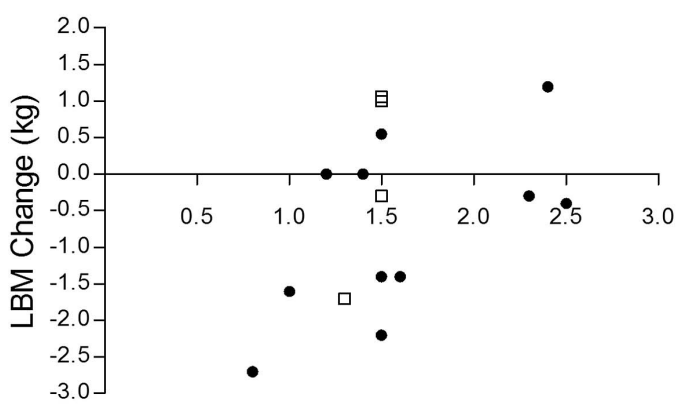

g protein $/ \mathrm{kg} / \mathrm{d}$
Currently, there is a need for longer-term interventions to determine whether protein timing and balanced distribution translates into better retention of LBM in elite athletes.

Sleep is critical for recovery and performance of elite athletes, with average durations of sleep lasting $\sim \mathrm{hr}$ (Knufinke et al., 2018; Staunton et al., 2017), and represents a prolonged postabsorptive period where muscle protein balance is negative and could be improved. Indeed, presleep protein supplementation combined with exercise training has been shown to improve protein balance during the prolonged postabsorptive overnight period (Trommelen et al., 2017). In young men, protein ingestion before sleep during a 12-week progressive resistance training protocol resulted in increased muscle mass and strength gains compared to placebo (Snijders et al., 2015). Thus, presleep protein ingestion may be another strategy to improve LBM retention during caloric restriction.

Protein quality, assessed by the digestible indispensable amino acid score (DIAAS) may also be important for elite athletes undergoing caloric restriction, particularly when we consider that higher-quality proteins, including animal-based proteins, contain a higher proportion of essential amino acids, which are known to be potent stimulators of MPS (Tang et al., 2009). Indeed, during dietary energy restriction, whey protein (a fast-digested protein derived from milk that contains a high proportion of the branched chain amino acid leucine) ingestion resulted in a robust increase in MPS that was significantly higher than consumption of an isoenergetic and isonitrogenous amount of soy protein (Hector et al., 2015). In energy balance in young male novice weight lifters, the consumption of nonfat milk following resistance exercise, for 12 weeks, resulted in greater gains in LBM and greater reduction in fat mass compared to the consumption of soy protein (Hartman et al., 2007). During dietary energy restriction in untrained overweight/obese premenopausal women, consuming a higher protein from dairy diet ( $\sim 1.3 \mathrm{~g}$ protein $/ \mathrm{kg} /$ day) combined with aerobic and resistance training, resulted in superior loss of fat mass than a lower protein, lower dairy diet, as well as gains in LBM (Josse et al., 2011). Meta-analyses have demonstrated that increased dairy consumption during energy restriction resulted in superior lean mass retention and fat mass loss (Abargouei et al., 2012; Chen et al., 2012). Therefore, in addition to total protein consumption, the timing and quality of the protein ingested may be of importance during dietary energy restriction. However, it is important to note that much of this work on protein timing and quality has not been conducted in elite athletes, and this is an area for future research.

\section{Protein-Derived Supplements to Promote High-Quality Weight Loss}

Another method to promote high-quality weight loss in a restricted energy budget is the use of dietary supplements. For example, when whey protein was supplemented into an energy-restricted diet $(-500 \mathrm{kcal} /$ day $)$ in obese participants for 12 weeks, there was a greater loss of fat mass (3.63 vs. $2.11 \mathrm{~kg}$ ) and reduced loss of LBM $(1.07 \mathrm{vs.} 2.41 \mathrm{~kg}$ ) (Frestedt et al., 2008). A meta-analysis reported that whey protein, either as a supplement or incorporated into a weight loss or weight maintenance diet, promoted LBM retention and fat mass loss (Miller et al., 2014). Thus, there is some evidence to support a role for whey, as a high-quality protein, in the promotion of high-quality weight loss during caloric restriction. Although not during energy restriction, a recent meta-analysis by Morton et al. (2017) demonstrated that protein supplementation enhanced strength and hypertrophy (Schoenfeld et al., 2013). 
had a positive effect on strength, muscle fiber cross-sectional area, and mid-femur cross-sectional area during prolonged resistance exercise training up to a total protein intake of approximately $1.6 \mathrm{~g}$ protein $/ \mathrm{kg} /$ day (95\% confidence interval, $1.03-2.20$ ), which is consistent with a previous meta-analysis on the same topic (Cermak et al., 2012). Taken together, protein supplementation would likely have a positive effect on high-quality weight loss for elite athletes during dietary energy restriction.

In addition to consuming a complete protein supplement, such as whey protein, ingestion of a supplement containing only the branched-chain amino acids (BCAAs; leucine, isoleucine, and valine) has been of interest for promoting skeletal muscle anabolism and high-quality weight loss. A common concern with BCAA supplementation is the antagonism of these amino acids in competing for the BCAA transporter. Indeed, isoleucine and valine have been shown to inhibit the absorption of leucine (Szmelcman \& Guggenheim, 1966), a potent stimulator of MPS. ChurchwardVenne et al. (2014) fed young men $\sim 6 \mathrm{~g}$ of whey protein supplemented with leucine, isoleucine, and valine to $5 \mathrm{~g}$ total leucine (W6 + BCAAs) or the same dose of whey protein supplemented with only $5 \mathrm{~g}$ leucine (W6 + High-Leu), and observed a less robust MPS response with W6 + BCAA compared to W6 + High-Leu. Interestingly, W6 + BCAA was accompanied by a lower leucine concentration in the plasma despite the same leucine content of the beverage. Importantly, only the W6 + High-Leu consumption resulted in a similar MPS response to the consumption of $25 \mathrm{~g}$ of whey protein (Churchward-Venne et al., 2014). Figure 2 shows the rates of myofibrillar protein synthesis in the $0-4.5 \mathrm{hr}$ period reported by Churchward-Venne et al. in the W25, W6 + High-Leu, and W25 groups (Churchward-Venne et al., 2014).

Dudgeon et al. (2016) placed young resistance-trained males on a carbohydrate energy restricted "cut diet" with heavy resistance training for 8 weeks and participants consumed $14 \mathrm{~g}$ BCAA before and after each workout or a carbohydrate control. The control group lost approximately $0.90 \pm 0.6 \mathrm{~kg} \mathrm{LBM}$, while the LBM in the BCAA group did not change $(0.4 \pm 0.7 \mathrm{~kg})$, and the control group lost approximately $1.4 \pm 0.4 \mathrm{~kg}$ fat mass, while the BCAA group lost $0.6 \pm 0.5 \mathrm{~kg}$ fat mass. Despite a significant lack of fat mass loss in the BCAA group during energy restriction, the authors concluded that "BCAA supplementation in trained individuals performing resistance training while on a hypocaloric diet can maintain lean mass and preserve skeletal muscle performance while losing fat mass" (Dudgeon et al., 2016, p. 1). This brings

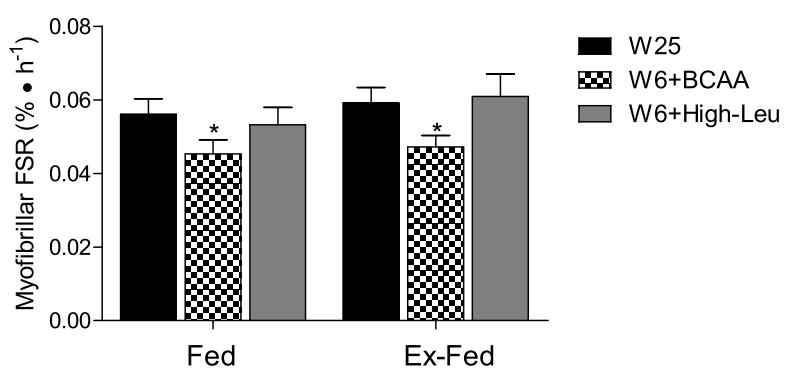

Figure 2 - Figure based on Churchward-Venne et al. (2014). Myofibrillar muscle protein synthesis (MPS) response over the $0-4.5 \mathrm{hr}$ period following ingestion of $25 \mathrm{~g}$ whey protein (W25), $6 \mathrm{~g}$ whey protein supplemented with branched-chain amino acids (BCAAs) (containing $5 \mathrm{~g}$ Leu, W6 + BCAA), or $6 \mathrm{~g}$ of whey protein supplemented with $5 \mathrm{~g}$ leucine (W6 + High-Leu). *Significantly different from W25 and W6 + High-Leu within that condition (Fed or Ex [exercise]-Fed). forth the question as to whether the retention of LBM (Dudgeon et al., 2016) was due to the effectiveness of the BCAA supplementation, or simply lack of a change in body mass (poor adherence to the diet). Thus, given the current data on BCAA supplementation, it seems equivocal to consume BCAA supplements during dietary energy restriction instead of a complete protein supplement such as whey protein, which has been shown to promote a robust increase in MPS during dietary energy restriction (Hector et al., 2015).

The leucine metabolite $\beta$-hydroxy- $\beta$-methylbutyrate (HMB) is currently prominently featured in the literature as a supplement with the potential to increase LBM and decrease fat mass, even during resistance exercise training in energy balance. For example, in recreationally-active young men, $3.42 \mathrm{~g} /$ day of free acid HMB ingestion was shown to stimulate MPS, although to a lesser extent than $3.42 \mathrm{~g} /$ day of leucine ingestion, and attenuated MPB (Wilkinson et al., 2013). Another study found improvements in LBM gains and fat mass loss following 12 weeks of HMB supplementation in highly-trained combat sports athletes compared to a placebo (Durkalec-Michalski et al., 2017). In trained individuals, HMB supplementation resulted in astonishing gains in LBM $(7.4 \pm 4.2 \mathrm{~kg})$ and concomitant loss of fat mass $(-5.4 \pm 1.6 \mathrm{~kg})$, despite no specific instruction to be energy deficit, following 12 weeks of supplementation and resistance training in energy balance (Wilson et al., 2014). Some studies have shown no change in body fat with HMB supplementation compared to placebo (Gallagher et al., 2000), and whether HMB provides an advantage over highquality protein supplementation such as whey, particularly during caloric restriction, has not yet been examined. Clearly, due to a number of conflicting studies (i.e., astonishing results in some studies; Wilson et al., 2014) and null findings in others (Gallagher et al., 2000), more work is needed to determine the effectiveness of HMB.

\section{Protein for Performance During Dietary Energy Restriction}

Many athletes may undergo aggressive weight loss protocols (particularly in weight-category sports) in order to rapidly achieve desired body weight. In a recent review, Fagerberg (2017) discussed the negative consequences of restricting calories too severely, particularly below $30 \mathrm{kcal} / \mathrm{kg}$ fat-free mass, which would be roughly equivalent to resting metabolic rate for most people (Loucks et al., 2011). For example, in natural male body builders, prolonged low energy availability can result in loss of LBM, hormonal imbalances, psychological issues, and fatigue (Fagerberg, 2017), all of which could have a negative impact on the health and performance of the athletes. Thus, all athletes, regardless of the varying physical demands of training and competition, should avoid extremely low energy weight loss diets. In a pilot study, a high-protein, low-fat $(2.8 \mathrm{~g} / \mathrm{kg})$ diet resulted in less stress and fatigue than a moderate protein moderate fat $(1.6 \mathrm{~g} / \mathrm{kg})$ diet in male weightlifters during a 2 -week $40 \%$ energy deficit, and approximately $160 \mathrm{~g}$ carbohydrates per day (Helms et al., 2015). Higher protein diets are clearly important for the maintenance of LBM during weight loss, which may be advantageous for performance or aesthetic reasons (Sundgot-Borgen \& Garthe, 2011). Interestingly, in the study by Josse et al. (2011) in premenopausal women, in which consumption of a high-dairy, higher-protein energy-restricted weight loss diet resulted in LBM gains, the authors also reported greater improvements in strength compared 
to the lower protein lower dairy groups who completed the same exercise protocol throughout the intervention.

In addition to the reduction in energy, which would result in a reduction in total macronutrient intake, the increased dietary protein intake recommended for elite athletes must come at the expense of total fat and/or carbohydrate intakes. Sport nutrition guidelines (Thomas et al., 2016) highlight the importance of carbohydrate intake in maintaining athletic performance. Indeed, current recommendations for carbohydrate intakes for athletes are 5-7 g/kg/day for modest (likely aerobic) exercise ( $1 \mathrm{hr} /$ day) (Thomas et al., 2016). However, this level of intake may neither be achievable nor necessary during dietary energy restriction with high protein intake. For example, in the weight loss study by Longland et al. (2016), the higher protein diet $(2.4 \mathrm{~g} / \mathrm{kg} / \mathrm{day})$ was created by reducing the fat content of the diet and keeping both groups ( $1.2 \mathrm{~g}$ protein $/ \mathrm{kg} /$ day and $2.4 \mathrm{~g}$ protein $/ \mathrm{kg} /$ day) at $\sim 3 \mathrm{~g}$ carbohydrate/kg/day. Longland et al. (2016) demonstrated similar improvements in exercise performance between both groups, including isometric knee extensor torque, 1-repetition maximum (1RM) bench and leg press, Wingate anaerobic test, and cycle ergometer time trial. In resistance-trained athletes, Mettler et al. (2010) investigated the impact of a 40\% energy deficit for 2 weeks, consuming $1 \mathrm{~g}$ protein $/ \mathrm{kg} /$ day or $2.3 \mathrm{~g}$ protein $/ \mathrm{kg} /$ day with approximately $3.4 \mathrm{~g}$ carbohydrates/kg/day. Participants maintained their habitual training throughout the intervention: $\sim 5$ sessions per week, including two or more resistance training sessions per week. Mettler et al. (2010) demonstrated that the higher protein diet (2.3 g protein $/ \mathrm{kg} / \mathrm{d}$ ) was superior for preserving LBM, but there were no differences between groups for any performance measure, including no changes in maximal voluntary contraction, 1RM, jump peak force, and Wingate power output, and an increase of $7.2 \%$ in muscle endurance despite the severe caloric deficit. Garthe et al. (2011) assessed performance in elite athletes undergoing a slow rate ([SR] $0.7 \%$ loss of body per week, $8.5 \pm 2.2$ weeks) or fast rate ([FR] $1 \%$ loss of body weight per week, $5.3 \pm 0.9$ weeks) of weight loss. Participants consumed $1.4-1.6 \mathrm{~g} / \mathrm{kg}$ protein and $3.2-3.5 \mathrm{~g}$ carbohydrate/ $\mathrm{kg}$ during the intervention and continued their sport-specific training protocol with four additional strength training sessions per week. Garthe et al. (2011) demonstrated an increase in LBM in SR and no change in LBM in FR. While the FR group showed no changes in performance, the SR group demonstrated an improvement in 1RM squat by $15.6 \pm 7.5 \%$ and bench press increased by $17 \pm 2.6 \%$, with no significant difference between groups for any time point (Garthe et al., 2011). However, the SR group also trained for longer $(8.5 \pm 2.2$ vs. $5.3 \pm 0.9$ weeks $)$ since the goal was to match total weight loss between the SR and FR groups. Finally, following a 30-day ketogenic diet (only $22 \mathrm{~g}$ carbohydrate per day), elite artistic gymnasts lost $\sim 1.9 \mathrm{~kg}$ fat mass, and a small but nonsignificant increase in LBM was observed, with no significant differences in strength tests (Paoli et al., 2012). Thus, it is possible to maintain or even increase performance during relatively severe energy restrictions, and for optimal performance, athletes should aim for a slower rate of weight loss and incorporate resistance exercise sessions.

\section{Influence of Higher Protein Intakes on Health}

Common concerns regarding the consumption of high-protein diets are the effects of elevated protein on kidney function and bone health, and the lack of scientific evidence to support these claims has been discussed in more detail in the following review articles (Phillips, 2017; Phillips et al., 2016). Put briefly, consumption of higher protein diets does not have detrimental effects on health, including kidney function (Longland et al., 2016), bone health (Shams-White et al., 2017), or liver function and blood lipids (Antonio et al., 2016a, 2016b).

\section{Weight Loss Supplements: Beyond Protein and Amino Acid Derivatives}

The primary driver of weight loss is the creation of an energy imbalance resulting in a net energy expenditure, and a number of supplements have been proposed to promote fat loss through a variety of mechanisms including increased fat oxidation and thermogenic effects (increased energy expenditure) (Jeukendrup \& Randell, 2011). However, there is limited scientific evidence demonstrated in systematic reviews, meta-analyses or randomized controlled trials for the efficacy of a number of substances including Garcinia cambogia, chitosan, $\beta$-glucans, raspberry ketone, glucomannan (konjac fiber), fucoxanthin, green coffee, Citrus aurantium (bitter orange), and Hoodia gordonii (Rios-Hoyo \& Gutierrez-Salmean, 2016). Although Ephedra has been shown to have thermogenic effects and be effective for weight loss (Shekelle et al., 2003), it is banned for use by athletes, illegal in many countries, and causes serious adverse side effects (Powers, 2001). Furthermore, many weight loss supplements may be contaminated with other substances that could cause negative health effects and result in an unintentional positive doping test (Mathews, 2018). Thus, in comparison to weight loss achieved through lifestyle modification (diet and exercise), weight loss supplements pose high risk (potential serious side effects and/or doping violations) with limited efficacy.

\section{Summary}

There is demonstrable benefit to the consumption of higher than recommended protein intakes, greater than the RDA, for promoting high-quality weight loss and maintaining or improving athletic performance during dietary energy restriction. The current recommendations for protein intake in elite athletes undergoing caloric restriction is $1.6-2.4 \mathrm{~g}$ protein $/ \mathrm{kg} / \mathrm{day}$, and the protein requirements can shift within this range (illustrated in Figure 3) depending on a number of factors including the rate of weight loss (i.e., faster rate of weight loss may promote a leftward shift, indicating greater protein requirements; Figure 3) and type of training (i.e., resistance exercise may promote a rightward shift, indicating lower protein requirements; Figure 3), and more sport-specific recommendations for total protein intake may help to improve various athletes' adaptations to weight loss. In addition to increased total protein intake, protein requirements for athletes may be adjusted depending on their consumption of high-quality protein, an even distribution of protein intake throughout the day, and high-quality protein intake in close temporal proximity following exercise, particularly resistance exercise. Protein supplements, such as whey protein, are a convenient source of protein to promote MPS, and may help athletes achieve recommended protein intakes. Other supplements such as BCAA, HMB, and other herbal/natural substances do not appear to have the strong scientific evidence for their utility in supporting high-quality weight loss, and some may have negative side effects. 


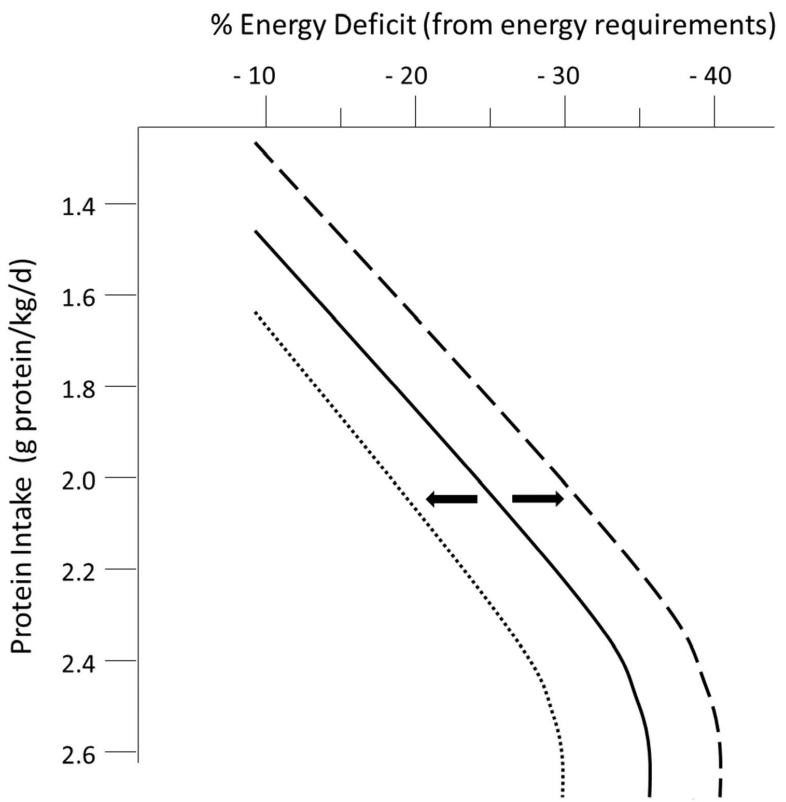

Figure 3 - Hypothetical illustration of protein requirements to spare lean mass increasing with greater energy deficits. A rightward shift of the curve (dashed line) indicates lower protein requirements. Similarly, a leftward shift of the curve (dotted line), indicates greater protein requirements. The plateau in the lines demonstrates that, with decreasing energy intake, increased protein intake becomes less effective to spare lean mass.

\section{Acknowledgments}

The manuscript preparation and editing was undertaken by AJH and SMP. All authors approved the final version of the paper.

\section{References}

Abargouei, A.S., Janghorbani, M., Salehi-Marzijarani, M., \& Esmaillzadeh, A. (2012). Effect of dairy consumption on weight and body composition in adults: A systematic review and meta-analysis of randomized controlled clinical trials. International Journal of Obesity (London), 36(12), 1485-1493. doi:10.1038/ijo.2011.269

Antonio, J., Ellerbroek, A., Silver, T., Vargas, L., \& Peacock, C. (2016a). The effects of a high protein diet on indices of health and body composition-a crossover trial in resistance-trained men. Journal of the International Society of Sports Nutrition, 13, 3. doi:10.1186/ s12970-016-0114-2

Antonio, J., Ellerbroek, A., Silver, T., Vargas, L., Tamayo, A., Buehn, R., \& Peacock, C.A. (2016b). A high protein diet has no harmful effects: A one-year crossover study in resistance-trained males. Journal of Nutrition and Metabolism, 2016, 1-5. doi:10.1155/2016/9104792

Areta, J.L., Burke, L.M., Camera, D.M., West, D.W., Crawshay, S., Moore, D.R., ... Coffey, V.G. (2014). Reduced resting skeletal muscle protein synthesis is rescued by resistance exercise and protein ingestion following short-term energy deficit. American Journal of Physiology-Endocrinology and Metabolism, 306(8), E989-E997. doi:10.1152/ajpendo.00590.2013

Areta, J.L., Burke, L.M., Ross, M.L., Camera, D.M., West, D.W., Broad, E.M., .. Coffey, V.G. (2013). Timing and distribution of protein ingestion during prolonged recovery from resistance exercise alters myofibrillar protein synthesis. The Journal of Physiology, 591(9), 2319-2331. doi:10.1113/jphysiol.2012.244897
Atherton, P.J., Smith, K., Etheridge, T., Rankin, D., \& Rennie, M.J. (2010). Distinct anabolic signalling responses to amino acids in C2C12 skeletal muscle cells. Amino Acids, 38(5), 1533-1539. doi:10.1007/s00726-009-0377-x

Bandegan, A., Courtney-Martin, G., Rafii, M., Pencharz, P.B., \& Lemon, P.W. (2017). Indicator amino acid-derived estimate of dietary protein requirement for male bodybuilders on a nontraining day is severalfold greater than the current recommended dietary allowance. The Journal of Nutrition, 147(5), 850-857. doi:10.3945/jn.116.236331

Cermak, N.M., Res, P.T., de Groot, L.C., Saris, W.H., \& van Loon, L.J. (2012). Protein supplementation augments the adaptive response of skeletal muscle to resistance-type exercise training: A meta-analysis. The American Journal of Clinical Nutrition, 96(6), 1454-1464. PubMed doi:10.3945/ajcn.112.037556

Chen, M., Pan, A., Malik, V.S., \& Hu, F.B. (2012). Effects of dairy intake on body weight and fat: A meta-analysis of randomized controlled trials. The American Journal of Clinical Nutrition, 96(4), 735-747. PubMed doi:10.3945/ajen.112.037119

Churchward-Venne, T.A., Breen, L., Di Donato, D.M., Hector, A.J., Mitchell, C.J., Moore, D.R., ... Phillips, S.M. (2014). Leucine supplementation of a low-protein mixed macronutrient beverage enhances myofibrillar protein synthesis in young men: A doubleblind, randomized trial. The American Journal of Clinical Nutrition, 99(2), 276-286. doi:10.3945/ajcn.113.068775

Dudgeon, W.D., Kelley, E.P., \& Scheett, T.P. (2016). In a single-blind, matched group design: Branched-chain amino acid supplementation and resistance training maintains lean body mass during a caloric restricted diet. Journal of the International Society of Sports Nutrition, 13, 1. doi:10.1186/s12970-015-0112-9

Durkalec-Michalski, K., Jeszka, J., \& Podgorski, T. (2017). The effect of a 12-week beta-hydroxy-beta-methylbutyrate (HMB) supplementation on highly-trained combat sports athletes: A randomised, doubleblind, placebo-controlled crossover study. Nutrients, 9(7), 753. doi:10.3390/nu9070753

Elango, R., Ball, R.O., \& Pencharz, P.B. (2008). Indicator amino acid oxidation: Concept and application. The Journal of Nutrition, 138(2), 243-246. doi:10.1093/jn/138.2.243

Elia, M., Stubbs, R.J., \& Henry, C.J. (1999). Differences in fat, carbohydrate, and protein metabolism between lean and obese subjects undergoing total starvation. Obesity Research, 7(6), 597-604. doi:10.1002/j.1550-8528.1999.tb00720.x

Erdman, K.A., Tunnicliffe, J., Lun, V.M., \& Reimer, R.A. (2013). Eating patterns and composition of meals and snacks in elite Canadian athletes. International Journal of Sport Nutrition and Exercise Metabolism, 23(3), 210-219. PubMed doi:10.1123/ijsnem.23.3.210

Fagerberg, P. (2017). Negative consequences of low energy availability in natural male bodybuilding: A review. International Journal of Sport Nutrition and Exercise Metabolism, 22, 1-31. doi:10.1123/ijsnem. 2016-0332

Frestedt, J.L., Zenk, J.L., Kuskowski, M.A., Ward, L.S., \& Bastian, E.D. (2008). A whey-protein supplement increases fat loss and spares lean muscle in obese subjects: A randomized human clinical study. Nutrition \& Metabolism (London), 5, 8. doi:10.1186/17437075-5-8

Gallagher, P.M., Carrithers, J.A., Godard, M.P., Schulze, K.E., \& Trappe, S.W. (2000). Beta-hydroxy-beta-methylbutyrate ingestion, Part I: Effects on strength and fat free mass. Medicine \& Science in Sports \& Exercise, 32(12), 2109-2115. PubMed doi:10.1097/00005768200012000-00022

Garthe, I., Raastad, T., Refsnes, P.E., Koivisto, A., \& Sundgot-Borgen, J. (2011). Effect of two different weight-loss rates on body composition and strength and power-related performance in elite athletes. 
International Journal of Sport Nutrition and Exercise Metabolism, 21(2), 97-104. PubMed doi:10.1123/ijsnem.21.2.97

Gillen, J.B., Trommelen, J., Wardenaar, F.C., Brinkmans, N.Y., Versteegen, J.J., Jonvik, K.L., . . van Loon, L.J. (2017). Dietary protein intake and distribution patterns of well-trained dutch athletes. International Journal of Sport Nutrition and Exercise Metabolism, 27(2), 105-114. doi:10.1123/ijsnem.2016-0154

Greenhaff, P.L., Karagounis, L.G., Peirce, N., Simpson, E.J., Hazell, M., Layfield, R., ... Rennie, M.J. (2008). Disassociation between the effects of amino acids and insulin on signaling, ubiquitin ligases, and protein turnover in human muscle. American Journal of PhysiologyEndocrinology and Metabolism, 295(3), E595-E604. PubMed doi:10.1152/ajpendo.90411.2008

Hartman, J.W., Tang, J.E., Wilkinson, S.B., Tarnopolsky, M.A., Lawrence, R.L., Fullerton, A.V., \& Phillips, S.M. (2007). Consumption of fat-free fluid milk after resistance exercise promotes greater lean mass accretion than does consumption of soy or carbohydrate in young, novice, male weightlifters. The American Journal of Clinical Nutrition, 86(2), 373-381.

Hector, A.J., Marcotte, G.R., Churchward-Venne, T.A., Murphy, C.H., Breen, L., von Allmen, M., ... Phillips, S.M. (2015). Whey protein supplementation preserves postprandial myofibrillar protein synthesis during short-term energy restriction in overweight and obese adults. The Journal of Nutrition, 145(2), 246-252. doi:10.3945/jn.114.200832

Helms, E.R., Zinn, C., Rowlands, D.S., \& Brown, S.R. (2014). A systematic review of dietary protein during caloric restriction in resistance trained lean athletes: A case for higher intakes. International Journal of Sport Nutrition and Exercise Metabolism, 24(2), 127-138. doi:10.1123/ijsnem.2013-0054

Helms, E.R., Zinn, C., Rowlands, D.S., Naidoo, R., \& Cronin, J. (2015). High-protein, low-fat, short-term diet results in less stress and fatigue than moderate-protein moderate-fat diet during weight loss in male weightlifters: A pilot study. International Journal of Sport Nutrition and Exercise Metabolism, 25(2), 163-170. PubMed doi:10.1123/ ijsnem.2014-0056

Heymsfield, S.B., Thomas, D., Nguyen, A.M., Peng, J.Z., Martin, C., Shen, W., ... Muller, M.J. (2011). Voluntary weight loss: Systematic review of early phase body composition changes. Obesity Revision, 12(5), e348-e361. doi:10.1111/j.1467-789X.2010.00767.x

Holt, S.H., Miller, J.C., Petocz, P., \& Farmakalidis, E. (1995). A satiety index of common foods. European Journal of Clinical Nutrition, 49(9), 675-690.

Humayun, M.A., Elango, R., Ball, R.O., \& Pencharz, P.B. (2007). Reevaluation of the protein requirement in young men with the indicator amino acid oxidation technique. The American Journal of Clinical Nutrition, 86(4), 995-1002. PubMed

Jeukendrup, A.E., \& Randell, R. (2011). Fat burners: Nutrition supplements that increase fat metabolism. Obesity Review, 12(10), 841-851. doi:10.1111/j.1467-789X.2011.00908.x

Josse, A.R., Atkinson, S.A., Tarnopolsky, M.A., \& Phillips, S.M. (2011). Increased consumption of dairy foods and protein during diet- and exercise-induced weight loss promotes fat mass loss and lean mass gain in overweight and obese premenopausal women. The Journal of Nutrition, 141(9), 1626-1634. doi:10.3945/jn.111.141028

Kato, H., Suzuki, K., Bannai, M., \& Moore, D.R. (2016). Protein requirements are elevated in endurance athletes after exercise as determined by the indicator amino acid oxidation method. PLoS ONE, 11(6), e0157406. PubMed doi:10.1371/journal.pone.0157406

Knufinke, M., Nieuwenhuys, A., Geurts, S.A., Coenen, A.M., \& Kompier, M.A. (2018). Self-reported sleep quantity, quality and sleep hygiene in elite athletes. Journal of Sleep Research, 27(1), 78-85. doi:10. $1111 /$ jsr.12509
Loenneke, J.P., Loprinzi, P.D., Murphy, C.H., \& Phillips, S.M. (2016). Per meal dose and frequency of protein consumption is associated with lean mass and muscle performance. Clinical Nutrition, 35(6), 1506-1511. doi:10.1016/j.clnu.2016.04.002

Longland, T.M., Oikawa, S.Y., Mitchell, C.J., Devries, M.C., \& Phillips, S.M. (2016). Higher compared with lower dietary protein during an energy deficit combined with intense exercise promotes greater lean mass gain and fat mass loss: A randomized trial. The American Journal of Clinical Nutrition, 103(3), 738-746. PubMed doi:10. 3945/ajcn.115.119339

Loucks, A.B., Kiens, B., \& Wright, H.H. (2011). Energy availability in athletes. Journal of Sports Sciences, 29(Suppl. 1), S7-S15. doi:10. 1080/02640414.2011.588958

Mamerow, M.M., Mettler, J.A., English, K.L., Casperson, S.L., ArentsonLantz, E., Sheffield-Moore, M., ... Paddon-Jones, D. (2014). Dietary protein distribution positively influences $24-\mathrm{h}$ muscle protein synthesis in healthy adults. The Journal of Nutrition, 144(6), 876-880. doi:10.3945/jn.113.185280

Manore, M.M. (2015). Weight management for athletes and active individuals: A brief review. Sports Medicine, 45(Suppl. 1), 83-92. doi:10.1007/s40279-015-0401-0

Mathews, N.M. (2018). Prohibited contaminants in dietary supplements. Sports Health, 10(1), 19-30. doi:10.1177/1941738117727736

Mettler, S., Mitchell, N., \& Tipton, K.D. (2010). Increased protein intake reduces lean body mass loss during weight loss in athletes. Medicine \& Science in Sports \& Exercise, 42(2), 326-337. PubMed doi:10. 1249/MSS.0b013e3181b2ef8e

Miller, P.E., Alexander, D.D., \& Perez, V. (2014). Effects of whey protein and resistance exercise on body composition: A meta-analysis of randomized controlled trials. Journal of the American College of Nutrition, 33(2), 163-175. PubMed doi:10.1080/07315724.2013. 875365

Moore, D.R., Churchward-Venne, T.A., Witard, O., Breen, L., Burd, N.A., Tipton, K.D., \& Phillips, S.M. (2015). Protein ingestion to stimulate myofibrillar protein synthesis requires greater relative protein intakes in healthy older versus younger men. The Journal of Gerontology. Series A, Biological Sciences and Medical Sciences, 70(1), 57-62. doi:10.1093/gerona/glu103

Morton, R.W., Murphy, K.T., McKellar, S.R., Schoenfeld, B.J., Henselmans, M., Helms, E., . . Phillips, S.M. (2017). A systematic review, meta-analysis and meta-regression of the effect of protein supplementation on resistance training-induced gains in muscle mass and strength in healthy adults. British Journal of Sports Medicine. doi: 10.1136/bjsports-2017-097608

Murphy, C.H., Churchward-Venne, T.A., Mitchell, C.J., Kolar, N.M., Kassis, A., Karagounis, L.G., ... Phillips, S.M. (2015a). Hypoenergetic diet-induced reductions in myofibrillar protein synthesis are restored with resistance training and balanced daily protein ingestion in older men. The American Journal of Physiology-Endocrinology and Metabolism, 308(9), E734-E743. doi:10.1152/ajpendo.00550. 2014

Murphy, C.H., Hector, A.J., \& Phillips, S.M. (2015b). Considerations for protein intake in managing weight loss in athletes. European Journal of Sport Science, 15(1), 21-28. doi:10.1080/17461391.2014. 936325

Paoli, A., Grimaldi, K., D’Agostino, D., Cenci, L., Moro, T., Bianco, A., \& Palma, A. (2012). Ketogenic diet does not affect strength performance in elite artistic gymnasts. Journal of the International Society of Sports Nutrition, 9(1), 34. PubMed doi:10.1186/1550-2783-9-34

Pasiakos, S.M., Cao, J.J., Margolis, L.M., Sauter, E.R., Whigham, L.D., McClung, J.P., . . . Young, A.J. (2013). Effects of high-protein diets on fat-free mass and muscle protein synthesis following weight loss: 
A randomized controlled trial. Faseb Journal, 27(9), 3837-3847. PubMed doi:10.1096/fj.13-230227

Phillips, S.M. (2014). A brief review of higher dietary protein diets in weight loss: A focus on athletes. Sports Medicine, 44(Suppl. 2), 149-153. doi:10.1007/s40279-014-0254-y

Phillips, S.M. (2017). Current concepts and unresolved questions in dietary protein requirements and supplements in adults. Frontiers in Nutrition, 4, 13. doi:10.3389/fnut.2017.00013

Phillips, S.M., Chevalier, S., \& Leidy, H.J. (2016). Protein "requirements" beyond the RDA: Implications for optimizing health. Applied Physiol Nutr Metab, 41(5), 565-572. doi:10.1139/apnm-2015-0550

Phillips, S.M., Fulgoni, V.L., 3rd, Heaney, R.P., Nicklas, T.A., Slavin, J.L., \& Weaver, C.M. (2015). Commonly consumed protein foods contribute to nutrient intake, diet quality, and nutrient adequacy. The American Journal of Clinical Nutrition, 101, 1346S-1352S. doi:10. 3945/ajcn.114.084079

Phillips, S.M., Tipton, K.D., Aarsland, A., Wolf, S.E., \& Wolfe, R.R. (1997). Mixed muscle protein synthesis and breakdown after resistance exercise in humans. American Journal of Physiology, 273(1 Pt 1), E99-E107.

Powers, M.E. (2001). Ephedra and its application to sport performance: Another concern for the athletic trainer? Journal of Athletic Training, 36(4), 420-424.

Rasmussen, B.B., \& Phillips, S.M. (2003). Contractile and nutritional regulation of human muscle growth. Exercise and Sport Sciences Reviews, 31(3), 127-131. doi:10.1097/00003677-200307000-00005

Rios-Hoyo, A., \& Gutierrez-Salmean, G. (2016). New dietary supplements for obesity: What we currently know. Current Obesity Reports, 5(2), 262-270. doi:10.1007/s13679-016-0214-y

Schoenfeld, B.J., Aragon, A.A., \& Krieger, J.W. (2013). The effect of protein timing on muscle strength and hypertrophy: A meta-analysis. Journal of the International Society of Sports Nutrition, 10(1), 53. doi:10.1186/1550-2783-10-53

Shams-White, M.M., Chung, M., Du, M., Fu, Z., Insogna, K.L., Karlsen, M.C., ... Weaver, C.M. (2017). Dietary protein and bone health: A systematic review and meta-analysis from the National Osteoporosis Foundation. The American Journal of Clinical Nutrition, 105(6), 1528-1543. PubMed doi:10.3945/ajcn.116.145110

Shekelle, P.G., Hardy, M.L., Morton, S.C., Maglione, M., Mojica, W.A., Suttorp, M.J., ... Gagne, J. (2003). Efficacy and safety of ephedra and ephedrine for weight loss and athletic performance: A metaanalysis. The Journal of the American Medical Association, 289(12), 1537-1545. doi:10.1001/jama.289.12.1537

Snijders, T., Res, P.T., Smeets, J.S., van Vliet, S., van Kranenburg, J., Maase, K., .. . van Loon, L.J. (2015). Protein ingestion before sleep increases muscle mass and strength gains during prolonged resistance-type exercise training in healthy young men. The Journal of Nutrition, 145(6), 1178-1184. doi:10.3945/jn.114.208371

Staunton, C., Gordon, B., Custovic, E., Stanger, J., \& Kingsley, M. (2017). Sleep patterns and match performance in elite Australian basketball athletes. Journal of Science and Medicine in Sport, 20(8), 786-789. doi:10.1016/j.jsams.2016.11.016

Sundgot-Borgen, J., \& Garthe, I. (2011). Elite athletes in aesthetic and Olympic weight-class sports and the challenge of body weight and body compositions. Journal of Sports Science, 29(Suppl. 1), S101-S114. doi:10.1080/02640414.2011.565783
Szmelcman, S., \& Guggenheim, K. (1966). Interference between leucine, isoleucine and valine during intestinal absorption. Biochemical Journal, 100(1), 7-11. doi:10.1042/bj1000007

Tang, J.E., Moore, D.R., Kujbida, G.W., Tarnopolsky, M.A., \& Phillips, S.M. (2009). Ingestion of whey hydrolysate, casein, or soy protein isolate: Effects on mixed muscle protein synthesis at rest and following resistance exercise in young men. Journal of Applied Physiology (1985), 107(3), 987-992. doi:10.1152/japplphysiol.00076.2009

Thomas, D.T., Erdman, K.A., \& Burke, L.M. (2016). American College of Sports Medicine Joint Position Statement. Nutrition and athletic performance. Medicine \& Science in Sports \& Exercise, 48(3), 543-568. PubMed doi:10.1249/MSS.0000000000000852

Trommelen, J., Kouw, I.W.K., Holwerda, A.M., Snijders, T., Halson, S.L., Rollo, I., ... van Loon, L.J.C. (2017). Pre-sleep dietary proteinderived amino acids are incorporated in myofibrillar protein during post-exercise overnight recovery. American Journal of Physiology Endocrinology and Metabolism. doi:10.1152/ajpendo.00273.2016

Trumbo, P., Schlicker, S., Yates, A.A., \& Poos, M. (2002). Dietary reference intakes for energy, carbohydrate, fiber, fat, fatty acids, cholesterol, protein and amino acids. Journal of the American Dietetic Association, 102(11), 1621-1630. PubMed doi:10.1016/S0002-8223 (02)90346-9

Volpi, E., Kobayashi, H., Sheffield-Moore, M., Mittendorfer, B., \& Wolfe, R.R. (2003). Essential amino acids are primarily responsible for the amino acid stimulation of muscle protein anabolism in healthy elderly adults. The American Journal of Clinical Nutrition, 78(2), 250-258. PubMed doi:10.1093/ajcn/78.2.250

Weinheimer, E.M., Sands, L.P., \& Campbell, W.W. (2010). A systematic review of the separate and combined effects of energy restriction and exercise on fat-free mass in middle-aged and older adults: Implications for sarcopenic obesity. Nutrition Reviews, 68(7), 375-388. doi:10.1111/j.1753-4887.2010.00298.x

Wilkinson, D.J., Hossain, T., Hill, D.S., Phillips, B.E., Crossland, H., Williams, J., ... Atherton, P.J. (2013). Effects of leucine and its metabolite beta-hydroxy-beta-methylbutyrate on human skeletal muscle protein metabolism. Journal of Physiology, 591(11), 2911-2923. doi:10.1113/jphysiol.2013.253203

Wilson, J.M., Lowery, R.P., Joy, J.M., Andersen, J.C., Wilson, S.M., Stout, J.R., . . Rathmacher, J. (2014). The effects of 12 weeks of beta-hydroxy-beta-methylbutyrate free acid supplementation on muscle mass, strength, and power in resistance-trained individuals: A randomized, double-blind, placebo-controlled study. European Journal of Applied Physiology, 114(6), 1217-1227. doi:10.1007/ s00421-014-2854-5

Wolfe, R.R. (2006). The underappreciated role of muscle in health and disease. The American Journal of Clinical Nutrition, 84(3), 475-482. PubMed

Wooding, D.J., Packer, J.E., Kato, H., West, D.W.D., Courtney-Martin, G., Pencharz, P.B., \& Moore, D.R. (2017). Increased protein requirements in female athletes after variable-intensity exercise. Medicine \& Science in Sports \& Exercise. doi:10.1249/mss.0000000000001366

Wycherley, T.P., Moran, L.J., Clifton, P.M., Noakes, M., \& Brinkworth, G.D. (2012). Effects of energy-restricted high-protein, low-fat compared with standard-protein, low-fat diets: A meta-analysis of randomized controlled trials. The American Journal of Clinical Nutrition, 96(6), 1281-1298. PubMed doi:10.3945/ajcn.112.044321 